containing unpublished results and notes of field work undertaken by the Survey are available to companies for reference. Much interest has been shown in the hydrocarbon potential of the sedimentary basin of West Greenland.

In cooperation with the Danish Atomic Energy Commission's Research Establishment at Risø work was continued on the evaluation of the radioactive mineral content of the Ilímaussaq intrusion in South Greenland, where some field work was carried out this year. Other economic investigations are mentioned above under Operations in Greenland.

Note

The following 19 articles report the principal activities of the 1971 field season in Greenland, together with the results of some of the isotopic age determination work carried out during the year. Articles dealing with North Greenland and central West Greenland come first, followed by those from southern West Greenland, South Greenland and East Greenland.

Unless otherwise stated at the end of each article, the authors' address is the Survey's headquarters in Copenhagen.

\title{
PRECAMBRIAN CRYSTALLINE ROCKS AND YOUNGER SEDIMENTS OF THE THULE DISTRICT, NORTH GREENLAND
}

\section{Peter R. Dawes}

Field work was carried out from mid-July to mid-September using a 22 foot boat hired from Innuterssuak Uvdloriak of Siorapaluk. Field assistance was given by Kakutsiak, Butdlak, Usakak and Naduk Uvdloriak. A reconnaissance was made along $500 \mathrm{~km}$ of coastline between Inglefield Bredning and Inglefield Land (figs 1 and 3). Pack ice stopped northerly progress south of Kap Hatherton $\left(78^{\circ} 25^{\prime} \mathrm{N}\right)$.

A review of work carried out by others, including P. Schei, L. Koch, R. Bentham, S. Munck, J. C. Troelsen and J. W. Cowie, is reserved for a later paper.

\section{Basement rock types}

In the Inglefield Bredning area three main units can be recognised (see fig. 3). These are:

(1) a unit of highly folded, biotite and hornblende gneisses which are commonly garnetiferous. The main type is a veined dark grey to reddish-brown weathering granodioritic gneiss; variations to granitic gneiss, augen gneiss and to pelitic schistose gneiss, rich in biotite, occur. In some areas grey to bluish-grey quartz-rich gneisses are common. The gneisses and associated amphibolite layers and inclu- 


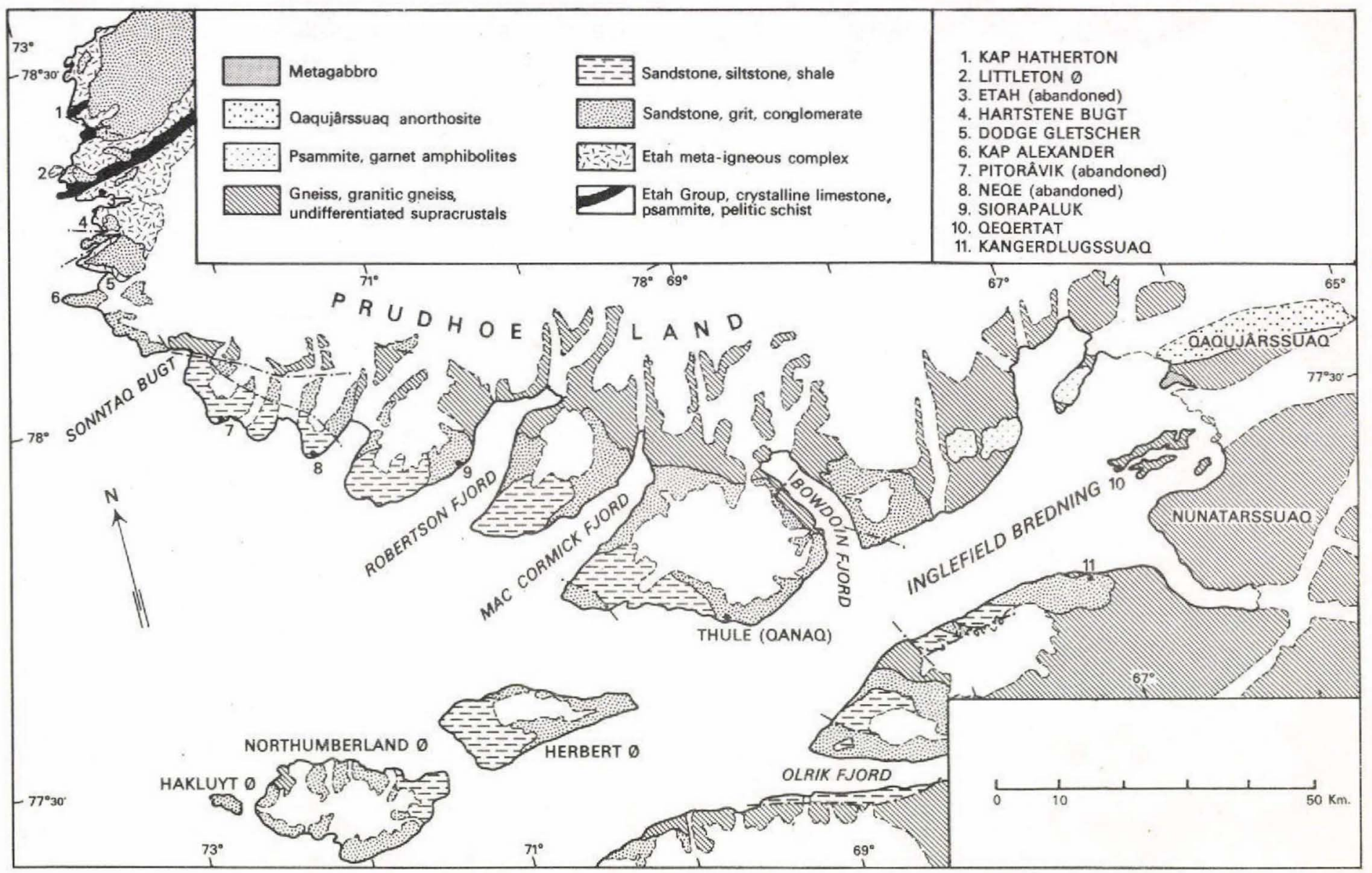

Fig. 3. Geological sketch map of the region between Inglefield Bredning and Inglefield Land, North Greenland, showing the names mentioned in the article by Dawes. Only the major faults are indicated. 
sions, are cut by several generations of undeformed aplites and pegmatites and a pink microgranite.

(2) a dark orange to reddish-brown unit of quartzite, meta-arkose and sillimanitebearing psammitic schist, with layers of amphibolite, forming a succession at least $800 \mathrm{~m}$ thick overlying unit (1). The amphibolites, which are extremely rich in garnet, and occur as concordant boudinaged sheets are considered as metamorphosed intrusions.

(3) a unit of white plagioclase-rich rocks, with an exposed thickness of over $3 \mathrm{~km}$, occupying about $180 \mathrm{~km}^{2}$ on Qaqujârssuaq. To the south, this Qaqujârssuaq anorthosite has a conformable contact with northerly-dipping schistose garnetbiotite gneisses; to the north it is lost under the Inland Ice. The rocks are medium grained and equigranular, and where traversed in the west they form a monotonous sequence with no mappable stratigraphy. A foliation of mafic, mainly amphibole, concentrations and schlieren indicate that the anorthosite has been severely deformed. Relic folds are cut by frequent basic dykes, the thickest noted being $45 \mathrm{~m}$. These are mainly concordant to the foliation of the anorthosite, and in the widest dykes, the rock varies from amphibolite schist in contact with the anorthosite to foliated metadolerite. Metagabbro showing similar textural variation, forms the south-western peninsula of Qaqujârssuaq and metabasites also occur along the contact of the anorthosite and within the gneisses to the south.

The Etah area is characterised by a mixed group of metasediments intruded by a suite of igneous rocks. These rocks have been metamorphosed and deformed together so that in the area north of Etah they are intimately associated. The rocks correspond to the Etah Formation of Koch (1929, p. 220), a name given to "sandstone and limestone penetrated by diorite and quartz-diorite". The use of a formational name for rocks of such diverse character is unfortunate. Berthelsen \& Noe-Nygaard (1965) suggest its abolition on other grounds.

Units of metasediments were mapped between Etah and Kap Hatherton, and according to Koch (1933) such rocks continue to eastern Inglefield Land. The name Etah Group is proposed here for this metasedimentary sequence with a type locality at the coast north-west of Etah, south of Littleton $\varnothing$. Here the succession is composed mainly of medium- to coarse-grained, white to light grey and cream-coloured crystalline limestone and white calc-silicate rocks, containing layers of biotite-garnet schist and psammitic rocks. The succession has a near-vertical attitude and a thickness, inclusive of associated meta-igneous rocks, of over $2 \mathrm{~km}$. Contact-type metamorphic minerals exist in both calcareous and pelitic rocks. Towards Kap Hatherton quartz-rich gneisses, regarded as transformed Etah Group arenaceous rocks, are common.

The igneous rocks around Etah, first noted by Schei (1903), are referred to here as the Etah meta-igneous complex. This complex varies in composition from 
black, dark grey and brown diorite and quartz-bearing norite, via hypersthene tonalite into grey, pink and red granodiorite and granitic rocks. The rocks show a marked range in character, e. g. west of Etah hypersthene-quartz diorite of igneous aspect is common while in Hartstene Bugt rocks of similar composition are veined hypersthene gneisses showing double-folded structural patterns. Despite intensive deformation transgressive contacts are preserved between the intrusive rocks and the Etah Group. Within the crystalline limestone of the type locality several generations of meta-igneous rocks are now isoclinally folded veins and sheets, most of which are severely boudinaged. Some plagioclase-rich layers may represent igneous anorthosite.

In Prudhoe Land no evidence was found for Koch's (1926) unit of syenite parallel to the coast. In Sonntag Bugt grey biotite-hypersthene granitic gneiss and foliated granite occur with quartzites and psammitic metasediments. These granulite facies rocks appear to continue on the nunataks north of Neqe and their association with the high-grade meta-igneous assemblages of the Etan area is probable. In the MacCormick-Robertson Fjord area, reddish biotite(-garnet) granitic gneiss and granite are associated with some amphibolitic and ultramafic material. In Bowdoin Fjord a succession of rusty weathering and severely folded, grey to brown garnet-biotite (-hornblende) schist and gneiss outcrops, in which concordant amphibolites occur. On the west coast biotite augen gneiss contains large pink feldspar porphyroblasts flattened in the plane of regional schistosity.

\section{Structure, correlation and age of the basement}

The regional foliation shows a strong tendency to NE to E-W and ESE strikes, a feature conspicuous north of Etah (Cowie, 1961) where the schistosity is steeply inclined, and at the head of Inglefield Bredning. In some areas strike variations between N-S and NW are frequent.

A basement-cover relationship may exist in the Inglefield Bredning area where the flattish-lying quartz-rich metasediments (unit 2 above) overlie darker gneisses along a sharp and conspicuous contact. Both units have been folded together and large-scale isoclines in the gneisses are refolded by open structures affecting the metasediments. The relationship of the Qaqujârssuaq anorthosite to these two rock units is unknown, although the extremely deformed nature of the anorthosite suggests affinity with the older gneisses. Likewise, the relationship of the quartzrich metasediments to the Etah Group is not known.

Some evidence suggests that the Etah Group was deformed prior to the intrusion of the Etah meta-igneous complex, after which polyphase deformation affected the whole area. The K/Ar date of $1740 \mathrm{~m}$. y. (Larsen \& Møller, 1968) on a gneiss from the Carey Øer, $120 \mathrm{~km}$ south-west of Thule, indicates that late plutonic activity of Hudsonian age affected the basement. In view of the long history of events now recognised, there is a reasonable possibility that crustal material of early Precambrian age composed part of the basement in western North Greenland. 
Unmetamorphosed sedimentary rocks

Unmetamorphosed and apparently unfossiliferous sediments of uncertain age (Thule Formation of Koch, 1929) outcrop throughout the area, overlying the basement with angular unconformity. The succession varies from less than $200 \mathrm{~m}$ in Inglefield Land to over $2.5 \mathrm{~km}$ to the south in the Thule Basin.

The Rensselaer Bay Sandstone (Troelsen, 1950) was traced from south-east of Kap Hatherton, where it is about 160 m thick to north of Kap Alexander where it thickens to over $260 \mathrm{~m}$. Provisional correlation with the area south of Dodge Gletscher suggests an increase to over $350 \mathrm{~m}$.

South of Sonntag Bugt a lower unit composed almost exclusively of clastics is clearly distinguished from an upper unit of alternating thinly-bedded argillaceous and arenaceous rocks. Sandstones, grits and conglomerates of the lower unit show well-developed cross-bedding and ripple marks and they are often highly ferruginous. Pebbles are composed mainly of quartz, with occasional granite, gneiss and other crystalline rocks. In the Inglefield Bredning area, the lower unit exceeds $1.5 \mathrm{~km}$ thick, and can be divided into a basal purplish-red section of ferruginous clastics with abundant conglomerates, and an overlying buff-coloured section, which to the east of Thule reaches about $1 \mathrm{~km}$ thickness.

The upper unit, which overlies the lower clastic unit with apparent conformity, is dark grey to yellowish-brown, composed of well-bedded impure quartzites, sandstones, siltstones and shales. The top of the succession is not seen, and the exposed thickness exceeds $1 \mathrm{~km}$. The unit is well exposed in the flat-lying sections in the headlands between Sonntag Bugt and Thule.

\section{Structure, basic intrusion and age of the younger sediments}

The Rensselaer Bay Sandstone and the lower clastic unit south of Sonntag Bugt contain dolerite sills, the thickest of which exceeds $100 \mathrm{~m}$. Such intrusions are noticeably absent in the upper sedimentary unit in Prudhoe Land.

Both sills and sediments are faulted and broad folds are conspicuous affecting the upper sediment unit between Neqe and Thule. The clastics overlying the basement in Prudhoe Land dip to the south and south-west, in places up to $40^{\circ}$. The sediments lack macroscopic signs of metamorphism but the dolerite sills show varying degrees of alteration, and in some, the pyroxene has been substantially replaced by amphibole.

Following the flexuring and at least some of the faulting, basic dykes were intruded. A main swarm of ESE-trending dykes is conspicuous cutting the youngest sediments in Prudhoe Land and along, and to the south of, Inglefield Bredning. A few NW-trending olivine-bearing dykes cut the basement at the head of Inglefield Bredning.

The age of the sediments and basic intrusions is unknown. An extensive search revealed only the stromatolite structures and fucoidal markings known previously. If the isotopic age work now being performed on dolerite material proves that all, 
or some of, the igneous sills are contemporaneous with those dated elsewhere in North Greenland (Henriksen \& Jepsen, 1970) then some sediments, including the Rensselaer Bay Sandstone, must be pre-Palaeozoic. On the other hand, if the Rensselaer Bay Sandstone in Canada, and thus in Greenland is of Cambrian age (Kerr, 1967), correlation between Inglefield Land and the area south of Dodge Gletscher suggests that at least $1 \mathrm{~km}$ of Palaeozoic deposits exists in Prudhoe Land and probably over $2 \mathrm{~km}$ in the entire Thule Basin.

\section{References}

Berthelsen, A. \& Noe-Nygaard, A. 1965: The Precambrian of Greenland. In Rankama, K. (editor): The Precambrian, 2, 113-262. London: Interscience Publishers.

Cowie, J. W. 1961: Contributions to the geology of North Greenland. Meddr Gronland 164, $3,47 \mathrm{pp}$.

Henriksen, N. \& Jepsen, H. F. 1970: K/Ar age determination on dolerites from southern Peary Land, North Greenland. Rapp. Gronlands geol. Unders. 28, 55-58.

Kerr, J. W. 1967: Stratigraphy of central and eastern Ellesmere Island, Arctic Canada. Part 1. Proterozoic and Cambrian. Pap. geol. Surv. Can. 67-27, pt. 1, 63 pp.

Koch, L. 1926: A new fault zone in Northwest Greenland. Am. J. Sci., 5th Ser. 12, 301-310.

Koch, L. 1929: Stratigraphy of Greenland. Meddr Grønland 73, 2 Afd. 2, 205-320.

Koch, L. 1933: The geology of Inglefield Land. Meddr Gronland 73, 1 Afd. 2, 38 pp.

Larsen, O. \& Møller, J. 1968: K/Ar age determinations from western Greenland. I. Reconnaissance programme. Rapp. Gronlands geol. Unders. 15, 82-86.

Schei, P. 1903: Summary of geological results. The Second Norwegian Polar Expedition in the 'Fram'. Geogr. J. 22, 56-65.

Troelsen, J. C. 1950: Contributions to the geology of Northwest Greenland, Ellesmere Island, and Axel Heiberg Island. Meddr Grønland 149, 7, 86 pp.

\section{GEOLOGICAL AND GEOPHYSICAL WORK IN CENTRAL WEST GREENLAND}

\section{Gilroy Henderson}

During the summer a new programme for the detailed geological and geophysical investigation of the Cretaceous-Tertiary sedimentary and volcanic rocks of central West Greenland was embarked on. This programme follows on work already undertaken in this area since 1938 (see Rosenkrantz \& Pulvertaft, 1969; Henderson, 1969b; Rosenkrantz, 1970). Extensive areas of thick sediments and an extension of the volcanic rocks have been discovered in recent years offshore from central West Greenland. A review of the published information is given by Henderson (in press). It thus became clear that the onshore area is a key area and that a 